\title{
THE STUDY CORRELATION BETWEEN READING HABIT AND PRONUNCIATION ABILITY AT THE SECOND GRADE STUDENTS OF IKIP SILIWANGI
}

\author{
Aseptiana Parmawati \\ aseptianaparmawati@gmail.com
}

\author{
IKIP SILIWANGI
}

\begin{abstract}
Language has central role on intellectual development, social, and emotional students to supported success student and learn all of lessons. Literacy level are performation, functional, informational, and epistemic. Performative level means students able to read, to write, to listen, and to speak using symbols. Reading habit refers to the automatic process as the readers read the textual material and deriving meaning unconsciously. A good reading habit is important for the development of personalities and mental capacities. Students reading habit plays an important role in pronunciation mastery. This research used the correlation research. The objectives of the study is to reveal correlation between students' reading habit and their pronunciation ability at second grade students of IKIP Siliwangi. The finding was supported by the result of students' scores. The minimum score of habit is 71 and 65 for pronunciation ability. The maximum score of reading habit is 109 and 92 for pronunciation ability. The mean of reading habit is 92.60 and 78.73 for pronunciation ability. Standard deviation of reading habit is 8.85 and 6.31 for pronunciation ability. The researcher finds that the Pearson Product Moment of both variable is 0.373 . It means that the correlation between students' reading habit in English and their pronunciation ability was in low correlation because in the range of 0.20 0.40. From the result of the statistical calculation, it can be synthesized that Null Hypothesis (Ho) is rejected. The researcher concluded that there is the correlation between students' reading habit and their pronunciation ability.
\end{abstract}

Keywords: Reading habit, Pronunciation, Correlation

\section{A. INTRODUCTION}

Language has central role on intellectual development, social, and emotional students to supported success student and learn all of lessons. Literacy level are performation, functional, informational, and epistemic. Performative level means students able to read, to write, to listen, and to speak using symbols. Functional level, students are able to use language to fulfill daily life such as reading newspaper, manual or instructional level, accessing language and knowledge ability on the other hand epistemic level. Many students can read or speak something and someone understands part of them but does not understand what they mean. Reading is an activity informed by the apprehension of images, shapes, patterns, and rhythms, which come to be recognized through repeated encounters and remembered forms; the meanings that are made in reading are in excess of the meanings that arise from the interpretation of written language (Lorange, 2014: 30). 
According to Zwiers (2004: 3), reading habits more clearly describes the automatic and unconcious process that are involved in constructing meaning from text. Moreover, Shen (2006: 559) identifies reading habits, as how often, how much, and what the readers read. It is a way of how the reader organizes his or her reading and how often, how much, and what the readers read. Students reading habit plays an important role in pronunciation mastery. Other people will understand meaning through reading with good pronunciation. Many people can read or speak something and someone understands part of them but does not understand what they mean.

Therefore, based on the description above, the objective of the study is to find out whether there is any positive correlation between the students'reading habit and their pronunciation at the second grade students of IKIP Siliwangi in the academic year of 2017/2018, and thus the hypotheses of the study are:

Ha : There is any positive correlation between students' reading habit and their pronunciation ability.

Ho : There is no correlation between students' reading habit and their pronunciation ability.

\section{B. LITERATURE REVIEW}

\section{Definition of Reading Habit}

Habit is a repeated performance. It is automated response disposition that are cued by aspects of the performance context (Neal, Wood, and Quinn 2004: 198). It is learned through a process in which repetition incrementally tunes cognitive processors in procedural memory (the memory system that supports the minimally conscious control of skilled action). This can be simplified that habit formation is the process by which new behavior become automatic, the behavioral patterns of one's repeat most often are etched into neural pathways.

According to Zwiers (2004: 3), reading habits more clearly describes the automatic and unconcious process that are involved in constructing meaning from text. Then, reading habit refers to the automatic process as the readers read the textual material and deriving meaning unconsciously. A good reading habit is important for the development of personalities and mental capacities. This habit is necessary for a healthy intellectual growth and plays a crucial role in enabling a person to achieve language proficiency (Grabe \& Stoller, 1997: 98).

Based on the description above, it can be cocluded that reading provides readers with great knowledge, by reading books frequently and having a good reading habit, the reader is able to analyze other's idea, which makes one think more critically.

\section{The Purpose of Reading Habit}

According to Ogbodo (2010:231-232) there are some reading habit purposes which have either positive or negative result, such as: hobbial, recreational, concentration, deviational.

a. Hobbial

A hobby is an activity that creates joy and satisfaction in doing it. The purpose of reading habit 
as a hobby make a reader knowledgeable in so many areas, such as in educational, politics, religious, and economic. This purpose of reading habit not only makes one satisfied but also positive. Unlike others hobbies, reading is one of the most recommended one to shape readers personality skill. By reading book particularly can develop the knowledge of vocabulary which helps in conversations. Reading as a hobby is wonderfull; it helps the readers to improve their ability to absorb and to comprehend written material and help them to pursue a better job.

\section{b. Recreational}

A good reading habit for recreational makes the reader acquire more knowledge in the classroom. Reading for relaxation is aimed to cool the reader's brain and to avoid mental fatigue; the example activities on reading for relaxation are reading newspaper and magazine.

\section{c. Concentration}

One of the reading habit purposes is concentration. Concentration means the readers acknowledge their reading process to understand the meaning of a passage. Reading for concentration is recommended for use in school by stakeholders; this reading habit purpose shows positive result in student's achievement in school.

\section{d. Deviational}

The last purpose of reading habit is deviational. This is the only reading habit which has a negative norm. The readers sometimes pretends to read, and deviates from the actual reading. This should be avoided by the students. If this habit reading attitude acquired by the students, it may lead to loss of interest in the acquisition of knowledge.

\section{The Aspect of Reading Habit}

According to Gaona (2011: 59-60) there are six aspects in gaining an effective reading habit, they are: reading frequency, books read, time spent on academic reading, time spent on nonacademic reading, motivation in the family environments, and motivation in the academic environments.

\section{a. Reading Frequency}

Reading frequency used to measure students' reading frequency in their spare time.

\section{b. Books Read}

The number of many books that the students have read in the last three months was included in the questionnaires.

\section{c. Time Spent on Academic Reading}

It is considered the time that the students devote their time to read academic book especially for their specialist subject.

d. Time Spent on Non-Academic Reading

It is discussed amount of time that the students used to read non-academic book, magazine, such as novel, fiction, romance, horror, etc.

e. Motivation in the Family Environment 
It focuses on the recommended book that purchased by the family based on the interest of the family.

f. Motivation in the Academic Environment

It is focuses on the frequency of students' reading literature in their academic environment.

\section{The concept of pronunciation}

Pronunciation is one of aspects that is important not only in speaking but also in other aspects in learning English. Pronunciation consists of vowels, consonants, and diphthongs. Fromkin, Rodman, and Hyams (2011) in Yusmita (2017) point out that English vowels are divided into two kinds of vowels, long vowels and short vowels. Long vowels consist of /a:/, /i:/, /u:/, /o:/,

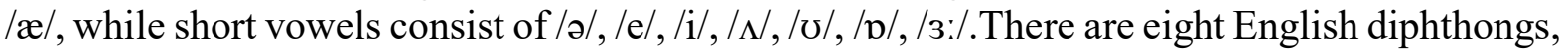
consist of /eI/, /aI/, /əv/, /av/, /oI/, /ıə/, /eə/, / / ə/.In addition, English consonants consist of

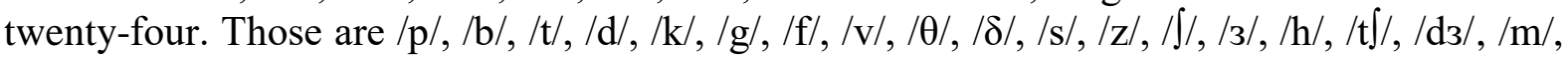
$/ \mathrm{n} /, / \eta /, / 1 /, / \mathrm{r} /, / \mathrm{w} /, / \mathrm{y} /$. It is essential for the students to understand phonetic symbols and sounds correctly. Pronunciation is the act of giving the true sounds of letters in words, and the true accents and quantity of syllables.

\section{RESEARCH METHODOLOGY}

The research conducted in the second grade students at IKIP Siliwangi in the academic year of 2017/2018. The campus is located at jl.Terusan Jenderal Sudirman no.3, Baros Cimahi Tengah, West Java. In the research, the researcher uses the correlation research. (Ary, Jacobs, Sorensen, Walker, \& Razavieh, 2010: 28) assumes that correlational research gathers data from individuals on two or more variables and then seeks to determine if the variables are related (correlated). Correlation means the extent to which the two variables vary directly (positive correlation) or inversely (negative correlation).

The degree of relationship is expressed as a numeric index called the coefficient of correlation. In this research the researcher took 30 subjects as sample from the population.The researcher use two instrument to collect the data by means of questionnaire of habit and pronunciation test.

\section{Questionnaire}

Questionnaires are any written instruments that present respondents with a series of questions or statements to which they are to react either by writing out their answers or selecting from among existing answers (Brown, 2001 in (Dornyei, 2003: 6). The researcher use the questionnaire to get the data about student's reading habit. The students only have to attach (V) marks on the scale that they choose.

\section{Pronunciation Test}

A test is a set of stimuli presented to an individual in order to elicit responses on the basis of which a numerical score can be assigned. This score, based on a representative sample of the individual's behavior, is an indicator of the extent to which the subject has the characteristic being measured (Ary et al., 2010: 201).

\section{FINDINGS AND DISCUSSION}

1. Descriptive Statistics

Table 1 
Descriptive Statistics

\begin{tabular}{|l|l|l|l|l|l|}
\hline & N & Minimum & Maximum & Mean & $\begin{array}{l}\text { Std. } \\
\text { Deviation }\end{array}$ \\
\hline Reading Habit & 30 & 71 & 109 & 92.60 & 8.854 \\
Pronunciation & 30 & 65 & 92 & 78.73 & 6.313 \\
Ability & & & & & \\
Valid N (listwise) & 30 & & & & \\
\hline
\end{tabular}

From the table above, there are 30 scores from both two variables, students' reading habit questionnaire and pronunciation ability test. The minimum score of reading habit is 71 and 65 for pronunciation ability. The maximum score of reading habit is 109 and 92 for pronunciation ability. The mean of reading habit is 92.60 and 78.73 for pronunciation ability. Standard deviation of reading habit is 8.85 and 6.31 for pronunciation ability.

a. Normality Test

Before the writer correlating the data, the writer then checks the normality of the data. The researcher uses SPSS program to find out whether the data normal or not.

Table 2

Normality Test

\begin{tabular}{|l|l|l|l|l|l|l|}
\hline & \multicolumn{3}{|l|}{ Kolmogorov-Smirnova } & \multicolumn{3}{l|}{ Shapiro-Wilk } \\
\cline { 2 - 7 } & Statistic & df & Sig. & Statistic & Df & Sig. \\
\hline Reading Habit & .091 & 30 & $.200^{*}$ & .983 & 30 & .900 \\
Pronunciation & .098 & 30 & $.200^{*}$ & .981 & 30 & .863 \\
Ability & & & & & & \\
\hline
\end{tabular}

*. This is a lower bound of the true significance.

b. Lilliefors Significance Correction

From the table above, significant of reading habit is 0.200 . Normality test result shows that significant number of reading habit tests score is higher than the level of significant $(0.900>$ $0.05)$, also significant number of pronunciation ability tests score is $(0.863>0.05)$. It means that students' reading habit questionnaire and pronunciation ability test are in normal distribution. After testing the normality value, the writer tries to find the correlation between reading habit and pronunciation ability.

c. Correlate Bivariative

After the researcher knows if the data is normal. Then the researcher correlates the data using 
SPSS program to find out wether the data have correlation or not.

Table 3

Correlations

\section{Analysis Result Correlation by Product Moment}

\begin{tabular}{|ll|l|l|}
\hline & & $\begin{array}{l}\text { ReadingHabi } \\
\mathrm{t}\end{array}$ & $\begin{array}{l}\text { Pronunciattion } \\
\text { Ability }\end{array}$ \\
\hline ReadingHabit & $\begin{array}{l}\text { Pearson } \\
\text { Correlation } \\
\text { Sig. (2-tailed) }\end{array}$ & 1 & $.373^{*}$ \\
& $\mathrm{~N}$ & 30 & .042 \\
& Pearson & $.373^{*}$ & 1 \\
\hline Pronunciation Ability & Correlation & & \\
& Sig. (2-tailed) & & \\
& & .042 & \\
& $\mathrm{~N}$ & 30 & 30 \\
\hline
\end{tabular}

*. Correlation is significant at the 0.05 level (2-tailed).

From the table above, the researcher finds that the Pearson Product Moment of both variable is 0.373 . It means that the correlation between students' reading habit in English and their pronunciation ability was in low correlation because in the range of $0.20-0.40$. The researchers also find that the sig (2-tailed) is 0.042 . The number of significant is lower than 0.05 . It can be concluded that Null Hypothesis (Ho) is rejected, while Alternative Hypothesis (Ha) is accepted.

\section{E. CONCLUSIONS}

Based on the result of the research, it can be concluded that there is low correlation between students' reading habit on English text and their pronunciation ability of the second grade students of IKIP Siliwangi in the academic year of 2017/2018.

The lecturer should give the best motivation and more creative in teaching by providing activities that can increase students' interest in reading, so the reading habit will run effectively.

\section{F. REFERENCES}

Ary, D., Jacobs, L. C., Sorensen, C. K., Walker, D. A., \& Razavieh, A. (2010). Introduction to Research in Education. Measurement (8th ed., Vol. 4). Canada: Nelson Education. Ltd.

Dornyei, Z. (2003). Questionnaires in Second Language Research: Construction, Administration, and Processing. New Jersey: Lawrence Erlbaum Associates, Inc. https://doi.org/10.1016/j.system.2011.06.001

Gaona, Julio Cesar Galacia. (2011). Relationship Between Reading Habits, University Library and Academic Performance in a Sample of Psychology Students, Superior Journal, Vol. XL (I), No. 157, 2011, pp. 59-60 
Grabe, W. and Stoller, F.L. (1997). Reading and Vocabulary Development in a Second Language: A Case Study. In Annamalay and Muniandy. 2013. Reading Habit and Attitude among Malaysian Polytechnic Students. International Journal of Education and Sciences. 5(1), 32-41

Lorange, Astrid. (2014). How Reading Is Written. A Brief Index to Gertrude Stein: Wesleyan University Press.

Neal, D.T., Wood, W., and Quinn, J.M. (2004). Habits -A Repeated Performance. Current Direction in Physiological Science. 15 (4).

Ogbodo Rosemary Ochanya (2010). Effective Study Habits in Educational Sector: Counseling Implications, Edo Journal of Counseling, Vol. 3. No. 2, 2010, pp 231-235

Shen, L. (2006). Computer Technology and College Students' Reading Habits. Chia-Nan Annual Bulletin, 32, 559-572.

Yusmita, A. and Anggraini, N (2017). The Effects of English Songs on the Seventh Grade Students' Pronunciation Achievement in SMP Srijaya Negara Palembang, Jurnal Bahasa dan Sastra, Vol. 6 (1), 1-20.

Zwiers, J. (2004). Builiding Reading Comprehension Habits in Grade 6-12. Sanfransisco, CA: International Reading Association. 